Artigo / Article

\title{
Fatores moduladores da gravidade da evolução clínica da anemia falciforme
} Modifiers factors of clinical severity in sickle cell anemia

Maria Stella Figueiredo

\section{Introdução}

A anemia falciforme (AF) é doença monogênica causada por uma única mutação no gene da globina beta (HBB, Glu6Val). ${ }^{1}$ Essa alteração isolada faz com que a hemoglobina anormal resultante, a hemoglobina $\mathrm{S}(\mathrm{HbS})$, quando desoxigenada e em elevada concentração, apresente redução na solubilidade com formação de estruturas paracristalinas, levando a acentuada elevação da viscosidade sangüínea. ${ }^{2-4}$ Caracteristicamente, a AF apresenta variabilidade fenotípica evidente e, na tentativa de elucidar este fenômeno, pesquisas recentes têm mostrado que a fisiopatogenia desta doença é bastante complexa. Além de fatores próprios do eritrócito e da hemólise, inflamação, ativação endotelial e alterações em fatores vasoativos parecem ter papel importante no desencadeamento do fenômeno vaso-oclusivo (FVO). ${ }^{5-7}$

A elucidação do mecanismo de ação destes fatores moduladores da gravidade da AF permitirá a instituição de tratamentos individualizados, de acordo com a gravidade do fenótipo do paciente, evitando numerosas e desnecessárias intervenções. ${ }^{7}$

\section{Fatores moduladores relacionados ao eritrócito}

Desde que a concentração de HbS é fator determinante do início e da progressão da falcização, a habilidade do eritrócito manter sua hidratação, e conseqüente volume intracelular é importante na fisiopatologia da AF. ${ }^{6}$ Alterações no volume eritrocitário levam ao desbalanço da relação desidratação/ hidratação do eritrócito. Células com concentração de hemoglobina corpuscular média elevada, ou células densas, apresentam baixa afinidade pelo oxigênio, pouca deformabilidade, alta viscosidade, alta propensão à formação de polímeros de $\mathrm{HbS}$ na desoxigenação e menor sobrevida. ${ }^{3,8}$ Indivíduos com maior número de células densas têm maior grau de hemólise e de anemia, mas não necessariamente maior número de FVO. ${ }^{9}$

O conteúdo de água no eritrócito é afetado por fatores extracelulares, como a osmolaridade plasmática, e por fatores celulares, como o conteúdo de cátions., ${ }^{5,10} \mathrm{O}$ transporte de íons pela membrana eritrocitária é regulado por, pelo menos, três mecanismos:

a) co-transporte de potássio $\left(\mathrm{K}^{+}\right)$e cloro $\left(\mathrm{Cl}^{-}\right)$- ativo em hemácias jovens e desencadeado na presença de $\mathrm{pH}$ ácido ou meio hipotônico. Quando ativado, $\mathrm{K}^{+}$e $\mathrm{Cl}^{-}$deixam a célula e a água segue este fluxo, causando desidratação e conseqüente aumento na concentração de $\mathrm{HbS} ; 5,5,6,10$

b) canal de Gardos - canal de transporte de $\mathrm{K}^{+}$ativado pelo aumento do $\mathrm{Ca}^{2+}$ intracelular resultante da desoxigenação e falcização. $\mathrm{O}$ efluxo de $\mathrm{K}^{+}$é acompanhado pelo de água, causando desidratação celular;:5,6,9,10

c) transporte de troca de sódio $\left(\mathrm{Na}^{+}\right)$e hidrogênio

Disciplina de Hematologia e Hemoterapia - Escola Paulista de Medicina (EPM) - Universidade Federal de São Paulo (Unifesp).

Correspondência: Maria Stella Figueiredo

Disciplina de Hematologia e Hemoterapia - Unifesp/EPM.

Rua Botucatu, 740 - $3^{\circ}$ andar

04023-000 - São Paulo-SP - Brasil

Tel.: (55 11) 5576-4240 - Fax: (55 11) 5571-8806

E-mail: stella@hemato.epm.br 
$\left(\mathrm{H}^{+}\right)$- capaz de desidratar células que foram previamente muito hidratadas. Apresenta alta expressão em hemácias falciformes. ${ }^{9}$

Embora a presença de células falcizadas seja indispensável para a ocorrência da doença, outros fenômenos, causados por outros genes que não o mutado, chamados genes epistáticos, têm papel importante neste processo., ${ }^{2,8,11}$ Dentre os diferentes efeitos epistáticos que modulam a AF, a presença de determinantes genéticos no complexo do gene da cadeia $\beta$ e a coexistência da talassemia $\alpha$ têm sido bastante estudados. ${ }^{8,10,11}$ Os determinantes genéticos no complexo do gene da cadeia $\beta$ provavelmente interferem na expressão dos genes $\gamma$ e, conseqüentemente, na produção de hemoglobina fetal $(\mathrm{HbF}))^{8,10,11}$

A HbF (HBG1, HBG2, a $\gamma 2$ ) é o modulador da AF mais estudado e atua inibindo a polimerização da $\mathrm{HbS} .^{12} \mathrm{~A}$ concentração de $\mathrm{HbF}$ varia de $0,1 \%$ a $30 \%$ e é geneticamente controlada. O gene da HbS é encontrado em um múltiplo background genético, caracterizado pelos quatro haplótipos do gene da globina- $\beta{ }^{7}{ }^{710,12}$ Elementos regulatórios próprios destes haplótipos têm efeito na expressão da HbF. ${ }^{10,11} \mathrm{O}$ polimorfismo C-T na posição -158 do gene da globina ${ }^{\mathrm{G}} \gamma$ $\left(-158 \mathrm{C}-\mathrm{T}^{\mathrm{G}} \gamma\right)$, presente nos haplótipos Senegal e ÁrabeIndiano, está classicamente associado ao aumento da $\mathrm{HbF}$ e menor gravidade das manifestações clínicas. Entretanto, outros elementos regulatórios além deste polimorfismo ainda permanecem desconhecidos. ${ }^{1,7,10,11,13}$

As células $\mathrm{F}$ são também reguladas por outros loci, denominados QTL (quantitative trait loci). Até o momento, foram descritos três: a) QTL na posição $8 q$ - interage com o polimorfismo -158C-T ${ }^{\mathrm{G}} \gamma$ modulando a HbF; b) QTL na posição Xp22 - associado ao número de células F em uma família com $\beta$-talassemia; c) QTL na posição 6q22.3-23.2 - apresenta a correlação mais evidente com nível de $\mathrm{HbF}$ e vários genes desta região têm sido analisados. O gene $P D E 7 B$ parece ser o mais forte candidato a modulador da HbF. Este gene participa da via de inibição da produção de hemina, induzida pela expressão do RNA mensageiro da $\gamma$-globina, e diminui a atividade transcripcional do promotor desta globina. ${ }^{1,714-17}$

No Brasil, cerca de $20 \%$ dos pacientes com AF apresentam $\alpha$-talassemia concomitante. ${ }^{18,19} \mathrm{~A} \alpha$-talassemia reduz a concentração de HbS diminuindo, conseqüentemente, a falcização. ${ }^{20}$ Eventos vaso-oclusivos que são devidos à hemólise, tais como acidente vascular cerebral (AVC), úlceras de pernas, priaprismo e hipertensão pulmonar se beneficiam com a associação de $\alpha$-talassemia. Entretanto, episódios de dor, síndrome torácica aguda e osteonecrose, complicações mais dependentes da viscosidade sangüínea, são mais prevalentes na presença desta associação. . $, 7,19,20^{2}$

\section{Fatores moduladores extrínsecos ao eritrócito}

O paciente com AF apresenta vasculopatia onde o dano endotelial foi induzido por variados fatores, tais como célu- las falcizadas, inflamação, lesão decorrente da reperfusão, presença de radicais livres e diminuição da bioavaliabilidade de óxido nítrico (NO). ${ }^{6,9}$

Contagem leucocitária elevada no paciente sem crises (steady state) é considerada fator independente de risco para morte precoce. Além disso, a leucocitose está associada a várias complicações da $\mathrm{AF}$, tais como: $\mathrm{AVC}$, infarto cerebral silencioso, síndrome torácica aguda e priaprismo. ${ }^{6,21}$ Vários estudos mostram que os neutrófilos têm papel ativo no processo de vaso-oclusão, sugerindo que diferença na expressão gênica dos neutrófilos pode ser responsável por algumas das variações fenotípicas observadas na AF. . $, 7,21^{2}$

Os experimentos atuais mostram que o endotélio na AF encontra-se alterado. Células endoteliais circulantes de pacientes com AF mostram aumento da expressão de ICAM-1 (intercellular cell adhesion molecule), VCAM-1 (vascular cell adhesion factor) e fator tissular. É sabido que a interação entre células endoteliais e eritrócitos falciformes é mediada por citocinas inflamatórias, que se encontram elevadas em pacientes fora de crise., ${ }^{5,6,910}$ Portanto, de modo geral, o estado de ativação endotelial observado nestes pacientes parece ser fator contribuinte da oclusão vascular., ${ }^{1,5-7,9,10}$

É sabido que a destruição do glóbulo vermelho leva à liberação de hemoglobina no plasma e esta converte o NO em nitrato inativo. Paralelamente, a lise de eritrócitos libera arginase que destrói L-arginina, substrato para a produção de NO, contribuindo na diminuição da concentração de NO. O NO é importante cofator da enzima guanilato-ciclase, responsável pela conversão de GTP (trifosfato de guanosina) em cGMP (monofosfato de guanina cíclica) que leva ao relaxamento dos músculos lisos vasculares e vasodilatação. A baixa bioavaliabilidade de NO altera a homeostasia vascular, aumentando a ativação plaquetária e a adesão de moléculas ao endotélio, levando ao desvio do balanço constrição-rela-

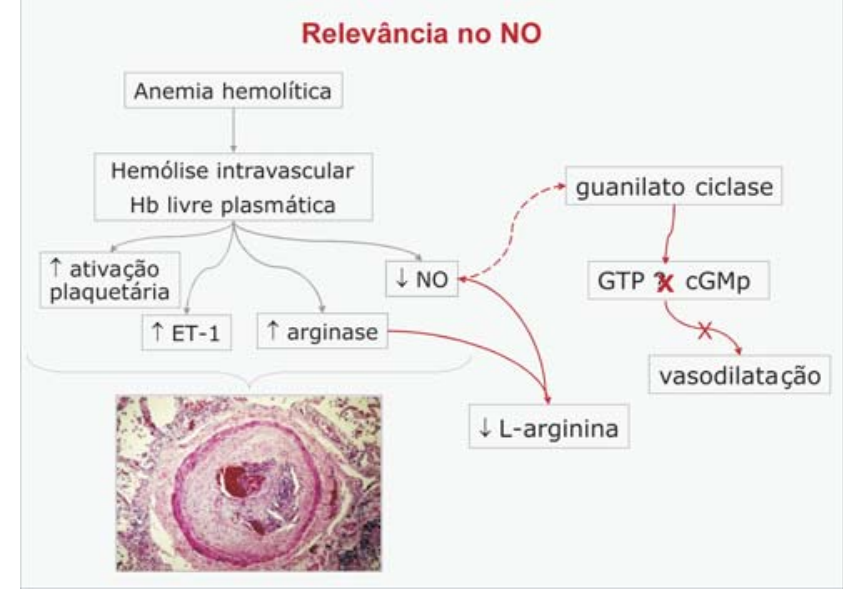

Figura 1. Relevância do óxido nítrico (NO) na fisiopatologia do fenômeno vaso-oclusivo, adaptado de Rother et al., 2005. ${ }^{22}$

$\mathrm{NO}=$ óxido nítrico; $\mathrm{ET}-1$ = endotelina- $1 ; \mathrm{Hb}=$ hemoglobina; GTP = trifosfato de guanosina; cGMP = monofosfato de guanina cíclica; $\downarrow$ = diminuição; $\uparrow=$ aumento 
xamento em direção a uma maior vaso-constrição, que aumenta a possibilidade de vaso-oclusão. ${ }^{6,9,22,23}$ (Figura 1)

$\mathrm{Na} A F$, o aumento do NO parece ter papel preponderante na propensão ao desenvolvimento de AVC, hipertensão pulmonar, úlceras de membros inferiores e priapismo., ${ }^{9,10,23}$

Efeitos ambientais podem também ter papel fundamental na expressão fenotípica da anemia falciforme. Temperaturas baixas podem induzir à dactilite e às crises de dor, ${ }^{8}$ e a desnutrição, comumente encontrada nesses indivíduos, pode interferir na expressão fenotípica da doença. ${ }^{24}$

\section{Conclusão}

Achados recentes reforçam a grande variedade de moduladores da gravidade clínica presente na AF e a importância de sua identificação. Aparentemente, dois eventos interrelacionados e desencadeados pela polimerização da $\mathrm{HbS}$ parecem ser responsáveis pelas manifestações clínicas da anemia falciforme: a vaso-oclusão e a anemia hemolítica. Estes processos dependem não só de aspectos relacionados ao eritrócito (conteúdo de polímero de HbS e grau de dano celular, por ex.) como da interação com fatores externos (dano endotelial, por ex.). ${ }^{9}$ Esta dicotomia de fenótipos, um dependente de hemólise e outro da vaso-oclusão, indica que os tratamentos poderão ser dirigidos preferencialmente contra distintos aspectos da fisiopatologia e que combinações de tratamentos provavelmente serão superiores a uma única modalidade. ${ }^{8,9}$

\begin{abstract}
Sickle cell anemia is a heterogeneous disorder with different degrees of clinical severity despite of being caused by a single base pair mutation (Glu6Val) of the ß-globin gene. Understanding this disease will allow us to discover therapies of specific pathophysiological targets. This article reviews some of the factors that can modulate the phenotype of sickle cell anemia, including red blood cell factors and factors extrinsic to the red blood cells.Rev. bras. hematol. hemoter. 2007;29(3):215-217.
\end{abstract}

Key words: Sickle cell anemia; modifying factors; epistatic genes; clinical severity.

\section{Referências Bibliográficas}

1. Steinberg MH, Adewoye AH. Modifiers genes and sickle cell anemia. Curr Opin Hematol. 2006;13:131-6.

2. Serjeant GR. Sickle cell disease. $2^{\mathrm{a}}$ edição. Oxford University Press; 1992. p. 631

3. Fabry ME, Kaul DK. Sickle cell vaso-occlusion. Hematol/Oncol Clin N Am. 1991;5:375-98.

4. Kaul DK, Nagel RL. Sickle cell vasoocclusion: many issues and some answers. Experientia. 1993;49:5-15.

5. Nagel RL. Severity, pathobiology, epistatic effects, and genetic markers in sickle cell anemia. Sem Hematol. 1991;28:180-201.

6. Madigan C, Malik P. Pathopysiology and therapy for haemoglobinopathies. Part I: sickle cell disease. Expert Ver. 2006;8:1-23.
7. Steinberg MH. Predicting clinical severity in sickle cell anaemia. Br J Haematol. 2005;129:465-81.

8. Schnog JB, Duits AJ, Muskiet FAJ, Ten Cate H, Rojer RA, Brandjes DPM. Sickle cell disease: a general overview. Neth J Med. 2004; 62:364-74.

9. Steinberg MH. Pathophysiologically based drug treatment of sickle cell disease. Trends Pharmacol Sci. 2006;27:204-10.

10. Stuart MJ, Nagel RL. Sickle-cell disease. Lancet. 2004;364:1343-60.

11. Nagel RL. Sickle cell anemia is a multigene disease: sickle painful crises, a case in point. Am J Hematol. 1993;42:96-101.

12. Adekile AD, Huisman THJ. HbF in sickle cell anemia. Experientia. 1993;49:16-27.

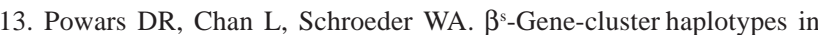
sickle cell anemia: clinical implications. Am J Ped Hematol/Oncol. 1990;12:367-74.

14. Garner CP, Tau T, Best $\mathrm{S}$ et al. Evidence of genetic interaction between the beta-globin complex and chromosome $8 \mathrm{q}$ in the expression of fetal hemoglobin. Am J Hum Genet. 2002;70:793-9.

15. Chang YC, Smith KD, Moore RD et al. An analysis of fetal hemoglobin variation in sickle cell disease: the reliable contribuctions of the $\mathrm{X}$-linked factor, $\beta$-globin haplotypes, $\alpha$-globin gene number, gender, and age. Blood. 1995;85:1111-7.

16. Wysynski DF, Baldwin CT, Cleves MA, et al. Polymorphisms near a chromosome 6q QTL area are associated with modulation of fetal hemoglobin levels in sickle cell anemia. Cell Mol Biol. 2004; 50:23-33.

17. Inoue A, Kuroyanagi Y, Terui K, et al. Negative regulation of gamma-globin gene expression by ciclic AMP-dependant pathway in erythroid cells. Exp Hematol. 2004;32:244-53.

18. Costa FF, Tavella MH, Zago MA. Deletion type $\alpha$-thalassemia among Brazilian patients with sickle cell anemia. Braz J Genet. 1989;12:605-11.

19. Figueiredo MS, Kerbauy J, Gonçalves MS, Arruda VR, Saad ST, Sonati MF et al. Effect of alpha-thalassemia and beta-globin gene cluster haplotypes on the hematological and clinical features of sickle-cell anemia in Brazil. Am J Hematol. 1996;53:72-6.

20. Steinberg MH, Embury SH. $\alpha$-thalassemia in blacks: genetic and clinical aspects and interactions with the sickle hemoglobin gene. Blood. 1986;68:985-90.

21. Okpala I. The intringuing contribution of white blood cells to sickle cell disease - a red cell disorder. Blood Rev. 2004;18:65-73.

22. Rother RP, Bell L, Hillmen P, Gladwin MT. The clinical sequelae of intravascular hemolysis and extracellular plasma hemoglobin. Jama. 2005;293:1653-62.

23. Kato GJ, Gladwin MT, Steinberg MH. Deconstructing sickle cell disease: reappraisal of the role of hemolysis in the development of clinical subphenotypes. Blood Rev. 2007;21:37-47.

24. Braga JAP. Avaliação do estado nutricional e importância dos oligoelementos zinco, cobre e ferro na doença falciforme. Tese de Mestrado da Escola Paulista de Medicina, 1992, 148 pp.

O tema apresentado e o convite ao autor constam da pauta elaborada pelo co-editor, prof. Rodolfo Delfini Cançado.

Avaliação: Co-editor e um revisor externo.

Publicado após revisão e concordância do editor.

Conflito de interesse: não declarado.

Recebido: 26/06/2007

Aceito: 09/08/2007 